\title{
Carbohydrate composition of ripe pineapple (cv. perola) and the glycemic response in humans
}

\author{
Composição de carboidratos do abacaxi (cv. pérola) e resposta glicêmica em humanos
}

\begin{abstract}
Beatriz CORDENUNSI ${ }^{1 *}$, Fulgêncio SAURA-CALIXTO ${ }^{2}$, Maria Elena DIAZ-RUBIO ${ }^{2}$, Angela ZULETA ${ }^{3}$, Marco Aurélio TINÉ4, Marcos Silveira BUCKERIDGE ${ }^{5}$, Giovanna Bezerra da SILVA ${ }^{5}$, Cecilia CARPIO ${ }^{6}$, Eliana Bistriche GIUNTINI ${ }^{7}$, Elizabete Wenzel de MENEZES ${ }^{1}$, Franco LAJOLO ${ }^{1}$
\end{abstract}

\begin{abstract}
Brazil is the third largest producer of pineapple (Ananas comosus) and the market for fresh pineapple is sustained by the Hawaii and Perola cultivars. In this work the Perola cultivar was divided into three main parts, shell, core and pulp, for characterization. Moisture in the pulp was higher (between 10 and 15\%) than in the shell and core. The amount of protein was higher in the core (35\%) than in the pulp and shell. Perola contained relatively low concentrations of total ascorbic acid in the edible parts, although higher levels of ascorbic acid in the shell. Citric acid corresponded to almost $60 \%$ of the total organic acids. The total soluble sugars $[\sim 7-12 \%$ (FW)] were predominantly sucrose, fructose and glucose. The core had almost twice as much total sugar (12\%) than the pulp (6.8\%). The amount of insoluble dietary fiber was around $1 \%$, and the soluble fiber was less than $0.1 \%$. The pulp showed the highest concentration of polyphenols $(0.49 \%)$ and antioxidant activity $\left(33 \mu \mathrm{mol} . \mathrm{g}^{-1}\right)$ out of the parts. The consumption of the pineapple pulp or core produced a high glycemic index ( 93\%), but considering the glycemic load, this fruit can be considered as low dietary.

Keywords: pineapple; Perola cultivar; carbohydrates; antioxidant activity; ascorbic acid; glycemic response.
\end{abstract}

\section{Resumo}

O Brasil é o terceiro maior produtor de abacaxi (Ananas comosus) e as principais cultivares encontradas no mercado são Havaí e Pérola. Neste trabalho, frutas da cultivar Pérola foram divididas em casca, cerne e polpa e analisadas. A umidade da polpa foi superior (entre 10 e $15 \%)$ à encontrada na casca e no cerne. A concentração de proteína foi maior no cerne (35\%) que na polpa e na casca. Essa cultivar contém baixas concentrações de ácido ascórbico nas partes comestíveis, no entanto a casca apresentou maiores níveis. O ácido cítrico correspondeu a aproximadamente $60 \%$ do total de ácidos orgânicos. Entre os açúcares solúveis [ 7-12\% (BU)], a sacarose, frutose e glicose foram predominantes. O cerne continha quase o dobro dos açúcares totais $(12 \%)$ em relação à polpa $(6,8 \%)$. A concentração de fibra alimentar insolúvel foi em torno de $1 \%$, enquanto a de fibra solúvel foi menor que $0,1 \%$. A polpa apresentou maior concentração de polifenóis $(0,49 \%)$ e maior atividade antioxidante $\left(33 \mu \mathrm{mol} . \mathrm{g}^{-1}\right)$ que as demais partes. O consumo da polpa e do cerne produziu alto índice glicêmico ( 93\%), mas considerando a quantidade usual consumida, o abacaxi apresenta baixa carga glicêmica.

Palavras-chave: abacaxi; cultivar Pérola; carboidratos; atividade antioxidante; ácido ascórbico; resposta glicêmica.

\section{Introduction}

The pineapple (Ananas comosus) from tropical America (Brazil and Paraguay) was initially domesticated by the Guarani Indians. Nowadays, it is cultivated in low altitudes in several countries where the weather conditions are favorable (www. geocities.com/nutriflip/Naturopathy/Pineapple.html). The pineapple is considered the third most important tropical fruit produced in the world, after the banana and citric fruits, and Brazil is its third largest producer. In international trade, the numerous pineapple cultivars are grouped into four main classes,
Smooth Cayenne, Red Spanish, Queen and Abacaxi, although there is much variation within each class (BARTOLOMÉ; RUPÉREZ, 1995).

Most of the commercial pineapple produced worldwide is canned prior to consumption; however, the fresh fruit market is increasing. Despite its favorable acceptance by consumers in North America and Europe, fresh pineapple has a few commercial limitations due to some deficiencies in the most widely cultivated

${ }^{1}$ Departamento de Alimentos e Nutrição Experimental, FCF, Universidade de São Paulo - USP, Av. Prof Lineu Prestes, 580, Bl 14, CEP 05508-900, São Paulo - SP, Brasil E-mail:hojak@usp.br; fmlajolo@usp.br;wenzelde@usp.br

2 Departamento de Metabolismo y Nutrición, CSIC - Instituto de Ciencia y Tecnología de Alimentos y Nutricion (ICTAN), Madrid, España, E-mail: fsaura@if.csic.es; medr@if.csic.es

${ }^{3}$ Facultad de Farmacia y Bioquimica, Universidad de Buenos Aires, Buenos Aires, Argentina, E-mail: azuleta@ffyb.uba.ar

${ }^{4}$ Seção de Fisiologia e Bioquímica de Plantas, Instituto de Botânica, CP 4005, São Paulo - SP, E-mail: marco.tine@gmail.com

${ }_{5}^{5}$ Departamento de Botânica, Instituto de Biociências, Universidade de São Paulo - USP, Rua do Matão, 277, São Paulo - SP, Brasil, E-mail: msbuck@usp.br

${ }^{6}$ Departamento de Ciencia de Alimentos y Biotecnología, Escuela Politécnica Nacional, Quito, Ecuador, E-mail: ccarpio@server.epn.edu.ec

PRONUT - Post Graduation Course - FCF/FEA/FSP-USP, E-mail: elibi@usp.br

${ }^{*}$ A quem a correspondência deve ser enviada 
variety in the world (Smooth Cayenne): high acidity, low concentration of ascorbic acid, little flavor and a texture defect known as translucency (PAULL; CHEN, 2003). Because it is a nonclimacteric fruit and seemingly has no carbon source for promoting post-harvest sweetening, the pineapple must be harvested sweet; sugar levels in pineapples will not accumulate post-harvest. Only the natural decrease in the organic acids present in the fruit might improve the post-harvest flavor of either a naturally low-sugar fruit or the one harvested early.

The average pineapple weighs between 1 and $2 \mathrm{~kg}$, and with regard to its consumption and utilization, it consists of the pulp, shell and core. The pulp, which is approximately $80 \%$ water, is consumed not only in natura but also in multiple processed forms, including juice, jam, dehydrated, canned or even frozen. Subproducts of pineapple processing include alcoholic beverages, organic acids, and the enzyme bromelain, which is a protease that is involved in the composition of several medicines and is also used as a meat softener. Both the shell and core of the pineapple are used for producing juices, because of their potential sources of fiber. Pineapple fiber is considered softer in texture than many vegetable sources, and some of its natural characteristics make it favorable for use in the food industry. These characteristics include its white color, its high retention of colorants and its high resistance to salts, vapor and traction (ROHRBACH; LEAL; D'EECKENBRUGGE, 2003). Currently there is no literature available on the pineapple core, probably because it is usually disposed of when canned pineapple is produced.

Although the nutritional composition of pineapple is well known, details of the composition of the pulp, shell and core of important cultivars produced in countries such as Brazil are still unknown. The market for fresh pineapple in Brazil is sustained by the Hawaii and Perola cultivars. The most commonly produced cultivar is the Hawaii; however, due to its low acidity and sweet flavor, Perola is gaining favor in the market and may yet become an acceptable fruit worldwide.

The consumption of rapidly digestible carbohydrates leads to fast increases in blood glucose and insulin. Therefore, meals rich in carbohydrates result in a rapid elevation of blood glucose levels (MENEZES; LAJOLO, 2006). The biomarkers known as the glycemic index (GI) and glycemic load (GL) classify the quality of carbohydrates and foods, respectively, according to their capacity to increase blood glucose. Knowing that foods have a low GI or low GL, may facilitate dietary planning and, thus, regulating glycemic levels (WHO/FAO, 2003). Because it is necessary to divulge information about the glycemic response produced by Brazilian foods, this information is available on the website of the Brazilian Food Composition Database (TBCA-USP) (www.fcf.usp.br/tabela).

The international cooperation projects CYTED/CNPq XI.18 (www.fcf.usp.br/cytedxi18) and 106PI0297 (www.fcf.usp. br/cyted106pi0297) aimed to study potential regional sources of carbohydrates. Pineapple is one of the fruits being widely studied through these projects and this work presents some of the results of the chemical and physiological features studied by project participants. In the present work, the chemical composition, antioxidant activity and glycemic response in healthy humans following the ingestion of the Perola cultivar pineapple were analyzed.

\section{Materials and methods}

\subsection{Material}

Fifteen ripe pineapples (Ananas comosus) of the Perola cultivar were obtained from the Companhia de Entrepostos e Armazéns Gerais de São Paulo (CEAGESP). After washing the surface, the fruits were separated into the shell, pulp and core, immediately frozen in liquid nitrogen, freeze-dried and pulverized. Samples of approximately $100 \mathrm{~g}$ of the different parts of the freeze-dried fruits were sent by express mail to the laboratories participating in the project. In order to supply the samples for the human study, the ripe pineapple was treated under the same conditions, and both the pulp and the core were freeze-dried on an industrial scale by Liotecnica Ind. Com. Ltda.

\subsection{Proximate composition}

The total protein content was determined by a semi-micro Kjeldahl method according to AOAC procedure 2055 (AOAC, 1995). The conversion factor used was 6.25. The ash content was determined by incineration in a muffle furnace at $520^{\circ} \mathrm{C}$. The moisture content of the sample was calculated based on weight loss after the sample was heated in an oven at $105^{\circ} \mathrm{C}$.

Dietary fiber. The dietary fiber of all the pineapple parts was quantified by an enzymatic-gravimetric method described by Lee, Prosky and Devries (1992).

\subsection{Carbohydrates determination}

Starch content was determined by a method previously described by Cordenunsi and Lajolo (1995). Soluble sugars were quantified following three extractions with $80 \%$ ethanol at $80^{\circ} \mathrm{C}$. The supernatants were combined, and the ethanol was evaporated under vacuum. The residues were reconstituted with water, filtered through $0.22 \mu \mathrm{m}$ membrane filters, and analyzed by high performance anion exchange chromatography-pulsed amperometric detection (HPAEC-PAD). The chromatographic analysis was performed on a Dionex DX 500 instrument equipped with a PAD system (ED 40). The analytical column employed was Carbopac PA1 $(250 \times 4 \mathrm{~mm}, 5 \mu \mathrm{m}$ particle size). The mobile phase was $18 \mathrm{mM} \mathrm{NaOH}$, and the flow rate was kept constant at $1.0 \mathrm{~mL} /$ minute. Injections $(25 \mu \mathrm{L})$ were made by using an AS 500 autosampler. Fructans were analyzed by the enzymatic-HPLC method, as described by Zuleta and Sambucetti (2001). The ion exchange column Aminex HPX87C (Bio-Rad) was calibrated with the sugars glucose, fructose, galactose, lactose, maltose and sucrose from Sigma and inulin and raftilin from Oraft (Belgium). Deionized water at $85^{\circ} \mathrm{C}$ was used as mobile phase with a flow rate of $0.6 \mathrm{~mL} /$ minute. Sugars were detected by the refraction index (Waters R40). Watersoluble polysaccharides (WSP) were extracted from $10 \mathrm{~g}$ of lyophilized samples for 1 hour at $80^{\circ} \mathrm{C}$ with continuous shaking. After filtration with nylon, the supernatant was dialyzed against distilled water for 3 days, with 2 changes per day, and then lyophilized. From the dry WSP produced $(50 \mathrm{mg}), 5 \mathrm{mg}$ were hydrolyzed according to Saeman, Buhl and Harris (1945). 


\subsection{Total antioxidant capacity of the phenolics associated to fiber - Indigestible Fraction (IF) determination}

The AOAC enzymatic-gravimetric method for dietary fiber determination in original grape materials, non-digested residues and non-fermented residues was followed (LEE; PROSKY; DEVRIES, 1992), with modifications developed in our laboratory (MAÑAS; SAURA-CALIXTO, 1993; MAÑAS; BRAVO; SAURA-CALIXTO, 1994; SAURA-CALIXTO et al., 2000). Samples were treated with a pepsin solution (Merck 7190) (100 mg pepsin. $\mathrm{mL}^{-1}$ of $\mathrm{HCl}-\mathrm{KCl}$ buffer $\mathrm{pH} 1.5$ ), a-amylase solution (Sigma A3176) (40 mg a-amylase/mL $\mathrm{mL}^{-1}$ Tris-Maleate buffer $\mathrm{pH}$ 6.9) and amyloglucosidase (Roche 102857) (pH of all solutions was checked before each enzymatic treatment). After these enzymatic treatments, the soluble and insoluble fractions were separated by centrifugation. The supernatants of the enzymatic treatment and the washings were combined and transferred into dialysis tubes (12000-14000 Molecular Weight Cut Off; Dialysis Tubing Visking, Medicell International Ltd., London, U.K.) and dialyzed against water for 48 hours at $25{ }^{\circ} \mathrm{C}$ (water flow $7 \mathrm{~L}$ /hour). Dialysates were then hydrolyzed with $1 \mathrm{M}$ sulfuric acid at $100{ }^{\circ} \mathrm{C}$ for 90 minutes, and the total indigestible fraction was measured with dinitrosalicylic acid (ENGLYST; CUMMINGS, 1998). The soluble indigestible fraction consisted of indigestible polysaccharides (neutral sugars and uronic acids), and the insoluble indigestible fraction was comprised of indigestible polysaccharides, indigestible protein and klason lignin. The total indigestible fraction was the sum of the soluble and insoluble indigestible fractions. The total antioxidant capacity was measured by two methods: FRAP (PULIDO; BRAVO; SAURA-CALIXTO, 2000), which measures the ability of plasma to reduce iron, and the ABTS method (RE et al., 1999), which measures the radical "scavenging" capacity. The antioxidant capacity was determined in aqueous-organic extracts of the samples (SAURA-CALIXTO; GOÑI, 2006). $0.5 \mathrm{~g}$ of sample were placed in a test tube and, after adding 20 $\mathrm{mL}$ of acidic methanol/water $(50: 50 \mathrm{v} / \mathrm{v}, \mathrm{pH}=2)$, the tube was thoroughly shaken at room temperature for 1 hour. The tube was centrifuged at $2500 \mathrm{~g}$ for 10 minutes and the supernatant was recovered. Twenty $\mathrm{ml}$ of acetone/water $(70: 30, \mathrm{v} / \mathrm{v})$ were added to the residue, and shaking and centrifugation were repeated. Finally, both methanolic and acetonic extracts were combined and used to determine antioxidant capacity and total polyphenols content (SINGLETON; ORTHOFER; LAMUELA-RAVENTÓS, 1999).

\subsection{Organic Acids}

The organic acids were determined as described by Pérez et al., (1997) with some modifications. The acid extraction was performed through homogenization of the lyophilized and pulverized samples ( 1 to $2 \mathrm{~g}$ ) in $30 \mathrm{~mL}$ of $\mathrm{H}_{2} \mathrm{SO}_{4}(0.02 \mathrm{~N})$ with metaphosphoric acid (0.05\%) and DL-homocistein (0.02\%) and stirring for 15 minutes. At the end of the process, the volume was collected and added water to reach to $50 \mathrm{~mL}$ and centrifuged at $6,900 \times \mathrm{g}$ for 8 minutes at $4{ }^{\circ} \mathrm{C}$. The supernatant was collected and filtered with a $0.45-\mu \mathrm{m}$ membrane (Millipore). The organic acids were analyzed with an HPLC (HP-1050) equipped with a UV-VIS detector at $270 \mathrm{~nm}$. All data were processed by an integrator HP 3396 series II. The isocratic separation of the organic acids was performed with a Bio Rad Aminex ${ }^{\circledast} \mathrm{HPX}-87 \mathrm{H}$ column at $30^{\circ} \mathrm{C}$. The mobile phase for acid ebullition was $\mathrm{H}_{2} \mathrm{SO}_{4}$ $(0.02 \mathrm{~N})$ with a flow rate of $0.5 \mathrm{~mL} /$ minute. External standards of malic, citric and tartaric acids were used for acid quantification with concentrations from 0 to $600 \mathrm{ppm}$.

\subsection{Ascorbic acid}

The ascorbic acid (AA) content was determined according to the method of Rizzolo, Forni and Poleselo (1984). AA was extracted with metaphosphoric acid $(0.3 \% \mathrm{w} / \mathrm{v})$ and analyzed by reversed-phase HPLC in a Hewlett Packard 1100 system with an autosampler and a quaternary pump coupled to a diode array detector. A $\mu$-Bondapack $(300 \times 3.9$ mm i.d., Waters, Milford, MA) column was used; the elution (flow rate of $1.5 \mathrm{~mL} /$ minute) performed under isocratic conditions with $0.2 \mathrm{M}$ sodium acetate/acetic acid buffer ( $\mathrm{pH} 4.2$ ) and monitored at $262 \mathrm{~nm}$. The total AA was estimated after the reduction of dehydroascorbic acid (DHA) with $10 \mathrm{mM}$ dithiothreitol.

\subsection{Human glycemic response investigations}

Eight healthy women volunteers with an average age of $26.0 \pm 4.3$ years old and normal body mass indices $\left(21.5 \pm 2.4 \mathrm{~kg} . \mathrm{m}^{-2}\right)$ participated in the study. The Ethical Research Committee of the School of Pharmaceutical Science, University of Sao Paulo, approved the experimental protocol (n.155), and the volunteers gave their written consent. The volunteers came to the laboratory once a week after a ten-hour fast. White bread (standard food) was tested twice in the first two weeks. In the third and fourth weeks, the volunteers ingested a portion of pineapple pulp or core, respectively. Each portion contained exactly $25 \mathrm{~g}$ of the available carbohydrates. The volunteers had ten minutes to ingest each portion with $150 \mathrm{~mL}$ of water. The blood glucose was determined for each subject on fast (time zero) and after food was ingested. Blood samples were taken at 15, 30, 45, 60, 90 and 120 minutes after food ingestion in order to construct a glycemic response curve (WOLEVER et al., 1991; BROUNS et al., 2005). Glucose was measured in the capillary whole blood by AccuCheck Advantage, Roche Diagnostics ${ }^{\circledR}$. The glycemic index (GI) of each sample was estimated by the relationship between the area under the curve for the test food and the area under the curve for the bread (standard - 100\%). The glycemic load (GL) of each food was calculated according to the following equation: GL = glycemic index (glucose as standard) $\times$ available carbohydrate $(\mathrm{g})$ per portion $\times 1 / 100$ (LIU et al., 2000; LUDWIG, 2003).

\section{Results and discussion}

\subsection{Chemical characteristics of Perola pineapple}

The pineapple fruit was divided into three main parts for the investigation of its utilization as in natura or processed pulp, or as the shell (as a fiber source) and the core, which is removed when the pulp is canned. Moisture in the pulp was around $15 \%$ higher than in the shell and core (Table 1). The level of protein was higher in the core (35\%) than in the pulp or the shell. Among the edible in natura components, the concentration of ash in the pulp was $25 \%$ higher than in the core. The varying 
concentrations of iron and calcium in the shell of the fruit are noteworthy. Each $100 \mathrm{~g}$ of shell has amounts of calcium and iron that correspond to 40 and $70 \%$ of the recommended daily intake for these minerals, respectively. In the case of the pulp, these values are 5 and $22 \%$, respectively, which are not relevant from a nutritional point-of-view (FAO/WHO, 2002).

The total soluble sugars found in the pineapple fruit (between 7 and 12\% in the fresh weight of the core and pulp) were predominantly sucrose, fructose and glucose (Table 2). The core has almost twice as much (12\%) sugar (glucose, fructose and sucrose) than the pulp (6.8\%). Furthermore, the concentration of sucrose is higher in the core than in the pulp, as the ratios of suc:glc+fru are 6.2 and 4 , respectively (Table 2 ). These results from the pulp are similar to the ones found by Bartolomé, Rupérez and Prieto (1995) in Smooth Cayenne and Red Spanish cultivars. The concentration of fructans $(\sim 0.1 \%)$ was the same as that found for starch. It is known that the concentration of starch, which is relatively high during the fruit development ( 4\%) (PAULL; CHEN, 2003), is low in developed fruit, but this had not previously been quantified in ripe fruit. In relation to the fructans, this is the first time that this fructose polymer was identified and quantified in pineapple. Because this fructose polymer has never been detected in Bromeliaceae, this data needs to be confirmed by a second methodology. The insoluble dietary fiber was found to be around $1 \%$ and the soluble dietary fiber was less than $0.1 \%$, with the total fiber concentration being comparable to the Smooth Cayenne cultivar (GORINSTEIN et al., 1999). Guevarra and Panlasigui (2000) found less than $1 \%$ of dietary fiber and negligible amounts of soluble fiber in this fruit.

\subsection{Vitamin C and organic acids}

The Perola pineapple presented relatively low concentrations of total ascorbic acid in the edible parts (Table 3); levels of ascorbic acid were higher in the shell, as expected, due to its protective antioxidant function (SMIRNOFF, 1996). This fact is corroborated by the high concentration of dehydroascorbic acid (DHAA) in the shell (1/3 of the total), whereas the concentration of DHAA was approximately $10 \%$ of the total in the pulp and core, as in some vegetables (SMIRNOFF, 1996). The core presented the lowest concentration of vitamin C ( 12 mg.100 g-1 FW).

As shown in Table 3, organic acids are distributed unevenly in pineapple due to the heterogeneous structure of the fruit. Free acids increase from the bottom of the fruit to the top, and to an even greater extent from the center towards the outside: 0.6 g. $100 \mathrm{~g}^{-1}$ core, 1.1 g. $100 \mathrm{~g}^{-1}$ pulp and $2.8 \mathrm{~g} .100 \mathrm{~g}^{-1}$ shell. The typical content of organic acids of fruit pulp ranges from 0.5 to 1.6 g. $100 \mathrm{~g}^{-1} \mathrm{FW}$; approximately $60 \%$ is citric acid, $36 \%$ is malic acid, and traces of succinic, oxalic and non-identified acids are also found (PY; LACOEUILHE; TEISSON, 1987). Furthermore, these values vary during pineapple growth and development, with the citric acid content changing from 0.1 g. $100 \mathrm{~g}^{-1}$ to $0.7 \mathrm{~g} .100 \mathrm{~g}^{-1}, 6$ and 15 weeks after flowering, respectively, in Smooth Cayenne (high acid and low acid clones) (SARADHULDHAT; PAULL, 2007). The results obtained for the Perola variety pulp $\left(1.1 \mathrm{~g} \cdot 100 \mathrm{~g}^{-1} \mathrm{FW}\right)$ were also within this range, as was the citric acid content (61\%). However, the percentage of malic acid was higher than that reported by Py, Lacoeuilhe and Teisson (1987). There is no information available about the organic acid content of the other parts of pineapple.

Table 1. Moisture, protein, ash (g.100 g $\left.{ }^{-1} \mathrm{FW}\right)$ and mineral content $\left(\mathrm{mg} .100 \mathrm{~g}^{-1} \mathrm{FW}\right)$ in the shell, pulp and core of Perola pineapple. Data presented are the means of triplicate assays \pm standard deviation.

\begin{tabular}{|c|c|c|c|c|c|}
\hline & Moisture & Protein & Ash & $\mathrm{Fe}$ & $\mathrm{Ca}$ \\
\hline & & g. $100 \mathrm{~g}^{-1} \mathrm{FW}$ & & \multicolumn{2}{|c|}{ mg. $100 \mathrm{~g}^{-1} \mathrm{FW}$} \\
\hline Shell & $72.92 \pm 0.07$ & $0.42 \pm 0.04$ & $0.53 \pm 0.01$ & $10.37 \pm 0.91$ & $395.19 \pm 8.78$ \\
\hline Pulp & $86.05 \pm 0.03$ & $0.35 \pm 0.02$ & $0.22 \pm 0.01$ & $3.24 \pm 0.15$ & $48.80 \pm 3.78$ \\
\hline Core & $78.09 \pm 0.03$ & $0.47 \pm 0.02$ & $0.16 \pm 0.03$ & $2.53 \pm 0.17$ & $10.41 \pm 0.99$ \\
\hline
\end{tabular}

FW means fresh weight.

Table 2. Carbohydrate content ( $\left.\mathrm{g} .100 \mathrm{~g}^{-1} \mathrm{FW}\right)$ in the pulp and core of Perola pineapple. Data presented are the means of triplicate assays \pm standard deviation.

\begin{tabular}{|c|c|c|c|c|c|c|c|}
\hline & \multicolumn{3}{|c|}{ Total soluble sugar } & \multirow{2}{*}{ Starch } & \multirow{2}{*}{ Fructans } & \multicolumn{2}{|c|}{ Dietary Fiber } \\
\hline & Glucose & Fructose & Sucrose & & & Soluble & Insoluble \\
\hline Pulp & $0.61 \pm 0.04$ & $0.82 \pm 0.03$ & $5.41 \pm 0.38$ & 0.1 & $0.15 \pm 0.01$ & $0.02 \pm 0.01$ & $0.78 \pm 0.03$ \\
\hline Core & $1.47 \pm 0.02$ & $1.71 \pm 0.02$ & $9.39 \pm 0.18$ & ND & ND & $0.11 \pm 0.01$ & $1.76 \pm 0.02$ \\
\hline
\end{tabular}

ND means not determined.

Table 3. Organic acid and ascorbic acid content (mg. $\left.100 \mathrm{~g}^{-1} \mathrm{FW}\right)$ in the shell, pulp and core of Perola pineapple. Data presented are the means of triplicate assays \pm standard deviation.

\begin{tabular}{|c|c|c|c|c|c|}
\hline & Citric acid & Malic acid & Ascorbic acid & Dehydroascorbic acid & Total ascorbic acid \\
\hline Shell & $1555 \pm 112$ & $1248 \pm 39$ & $18.65 \pm 0.52$ & $11.58 \pm 1.35$ & $30.24 \pm 1.86$ \\
\hline Pulp & $691 \pm 8$ & $444 \pm 20$ & $21.66 \pm 0.54$ & $2.49 \pm 0.35$ & $24.15 \pm 0.31$ \\
\hline Core & $373 \pm 11$ & $263 \pm 0$ & $10.96 \pm 0.57$ & $0.91 \pm 0.51$ & $11.87 \pm 0.31$ \\
\hline
\end{tabular}




\subsection{Non-starch polymers of Perola pineapple}

The high content of galactose, associated with the presence of rhamnose, suggests a high amount of pectic polysaccharides (Table 4). This pectin probably has a high quantity of branching points with neutral arabinogalactans (still unknown whether type I or II) and possibly arabinoxilan, a polymer that is composed of a main chain of xylose branched with arabinose. These components act mainly as soluble dietary fiber in the diet. We also observed a very low concentration of insoluble fiber, suggesting relatively little cellulose is present in the ripe fruit. The presence of relatively high proportions of xylose among the soluble polysaccharides suggests the presence of arabinoxylans. However, the presence of this polymer will have to be confirmed by structural analysis. If, indeed, this is confirmed, an important point to be stressed is that arabinoxylans have been shown to be implicated as a fiber hemicellulose associated with the decrease of glycemic levels in animals (De PAULA et al., 2005).

The dietary fiber content and composition of pineapple flesh has been reported by different authors (LUND; SMOOT, 1982; BARTOLOMÉ; RUPÉREZ, 1995). Voragen et al. (1983) extracted the different polysaccharide fractions from the ethanol-insoluble residue of the pineapple, and Bartolomé et al. (1995) reported on the partial characterization of the hemicellulosic fraction from pineapple fruit cell walls. However, there is little published information about the indigestible fraction in pineapple pulp.

Table 4. Water-soluble polymeric carbohydrates in the pulp of pineapple (cv. Pérola) (g.100 g $\left.{ }^{-1} \mathrm{DW}\right)$.

\begin{tabular}{crl}
\hline Monossacharide & \multicolumn{1}{c}{$\%$} & \multicolumn{1}{c}{ Possible polysaccharide } \\
\hline Galactose & 36.7 & galactan/arabinogalactan/galactomannan \\
Arabinose & 24.3 & arabinan/arabinogalactan \\
Xilose & 21.6 & xyloglucan/arabinoxylan \\
Glucose & 6.9 & Starch/xyloglucan \\
Manose & 6.3 & mannan/galactomannan \\
Fucose & 3.1 & xyloglucan \\
Rhamnose & 1.0 & Rhamnogalacturonan \\
\hline
\end{tabular}

DW means dry weight.
The dietary indigestible fraction (DIF) is defined as the part of vegetable foods that is neither digested nor absorbed in the small intestine, and therefore reaches the colon, where it serves as a substrate for fermentative microflora. It comprises dietary fiber, resistant protein, resistant starch and other indigestible associated compounds, such as cell wall polysaccharides. The analytical methodology for DIF determination in foods has already been reported (SAURA-CALIXTO et al., 2000).

The total indigestible fraction from pineapple pulp (14.96\% DW) had a high amount of insoluble fraction, with the insoluble fraction being its main constituent $(89 \%$ of total indigestible fraction) and the soluble fraction accounting for only $10 \%$ of total indigestible fraction.

The high amount of the insoluble indigestible fraction suggests that the hemicellulose, klason lignin and cellulose fractions (HUBER, 1983) are the main components of the indigestible fraction. In fact, the cellulose and hemicelluloses fractions were reported as the major constituents in the fiber composition of fresh pineapple (LUND; SMOOT, 1982; BARTOLOMÉ; RUPÉREZ; PRIETO, 1995). A fraction of resistant protein can be expected in the insoluble IF, as occurs in other fruits (JIMÉNEZ-ESCRIG et al., 2001; BRAVO; PERUMAL; SAURA-CALIXTO, 1999; LARRAURI et al., 1999).

\subsection{Antioxidant activity and polyphenols associated with the dietary fiber in pineapple}

Polyphenols and antioxidant activity (AA), which are a property derived from these bioactive compounds, associated with dietary fiber (LARRAURI; RUPÉREZ; SAURACALIXTO, 1997), were evaluated in the shell, pulp, and core of the pineapple fruit. The AA values and polyphenol concentrations of pineapple are shown in Table 5. The concentration of polyphenols (ca. $0.5 \%$ for pulp and $0.23 \%$ for core) is within the same range as in the nectarine (0.54\% DW) (CIESLIK; GREDA; ADAMUS, 2006), but quite lower than the concentration found in guava fruit (2.62\% DW) (JIMENEZ-ESCRIG et al., 2001). Also there is less AA antioxidant activity than in persimmons $\left(406 \mu\right.$ mol. $\left.\mathrm{g}^{-1} \mathrm{DW}\right)$

Table 5. Total phenolics and antioxidant activity associated with dietary fiber in the shell, pulp and core of Perola pineapple.

\begin{tabular}{|c|c|c|c|c|c|c|c|}
\hline \multirow{2}{*}{ Sample } & \multirow{2}{*}{$\%$ Total polyphenols } & \multicolumn{3}{|c|}{ Antioxidant Activity/g DW FRAP method } & \multicolumn{3}{|c|}{ Antioxidant Activity/g DW ABTS* method } \\
\hline & & $\mu \mathrm{mol}$ Tro-lox & $\mathrm{mg}$ vit $\mathrm{E}$ & mg vit $C$ & $\mu \mathrm{mol}$ Tro-lox & mg vit $\mathrm{E}$ & $\mathrm{mg}$ vit $\mathrm{C}$ \\
\hline Shell & $0.49 \pm 0.00$ & $29.13 \pm 0.90$ & $10.53 \pm 1.45$ & $3.70 \pm 0.53$ & $13.34 \pm 1.57$ & $7.49 \pm 0.66$ & $3.49 \pm 0.31$ \\
\hline Pulp & $0.49 \pm 0.06$ & $33.07 \pm 1.70$ & $12.36 \pm 1.01$ & $4.991 \pm 0.77$ & $10.50 \pm 0.51$ & $6.02 \pm 0.53$ & $2.62 \pm 0.13$ \\
\hline Core & $0.23 \pm 0.01$ & $16.26 \pm 0.48$ & $5.66 \pm 0.17$ & $1.91 \pm 0.06$ & $6.23 \pm 0.10$ & $4.45 \pm 0.04$ & $2.04 \pm 0.02$ \\
\hline
\end{tabular}

Table 6. Glycemic index (GI) and glycemic load (GL) of the pulp, core and total Perola pineapple.

\begin{tabular}{|c|c|c|c|c|c|}
\hline Food & $\begin{array}{c}\text { GI }(\%) \\
(\text { Bread }=100)\end{array}$ & $\begin{array}{c}\text { GI }(\%)^{a} \\
(\text { Glucose }=100)\end{array}$ & $\begin{array}{l}\text { Habitual portion } \\
\text { (g) }\end{array}$ & $\begin{array}{c}\text { Available carbohydrate } \\
\text { (gb/portion) }\end{array}$ & GL \\
\hline Bread (control) & 100 & 70 & 50 & 23 & 16 \\
\hline Pulp & $93 \pm 6$ & 65 & 90 & 9 & 6 \\
\hline Core & $95 \pm 7$ & 67 & 10 & 2 & 1 \\
\hline Total & - & 66 & 100 & 11 & 7 \\
\hline
\end{tabular}

$\mathrm{GI}^{\mathrm{a}}=\mathrm{GI}$ (bread as standard) $\times 0.7$. Available carbohydrate $\mathrm{b}-$ in the usual portion. $\mathrm{GL}^{\mathrm{c}}=\mathrm{a} \times \mathrm{b} / 100$. 
(GARCIA-ALONSO et al., 2004) or guava fruit $\left(238 \mu \mathrm{mol.g} \mathrm{g}^{-1}\right.$ DW). These differences are due to the presence of different polyphenols in each fruit; myricetin was the major polyphenol identified in pineapple fibers (LARRAURI; RUPÉREZ; SAURACALIXTO, 1997), whereas catechin is the principal phenolic compound in persimmons (SUZUKI et al., 2004). Perola showed the highest polyphenol concentration (0.49\%) and antioxidant activity $\left(33 \mu \mathrm{mol} . \mathrm{g}^{-1}\right)$ in the pulp and shell. The level of AA is correlated with the amount of polyphenols; the higher polyphenol concentration, the higher the AA. Differences between the pulp, shell, and core polyphenols are due to many different factors, but all of them relate to the pineapple variety, stage of pineapple maturity and storage post harvesting.

\subsection{Glycemic response}

High glycemic index (GI) foods are those with GI $\geq 95 \%$ and low glycemic index foods are those with GI $\leq 75 \%$, each considering white bread as the standard (100\%) (MENEZES; LAJOLO, 2006). The glycemic load (GL) was calculated for each food according to its GI and the amount of available carbohydrate present in the portion of food usually consumed by the population. Considering glucose as the standard, foods are classified as low GL $(\mathrm{GL} \leq 10)$ or high $\mathrm{GL}(\mathrm{GL} \geq 20)$. The intake of the pineapple pulp or core produced high glycemic responses with GI values of 93 and 95\%, respectively (Table 6). These high GI values could be related to the high concentration of soluble sugars and low concentrations of soluble fiber in the pineapple. However, when the pineapple glycemic load was calculated, this fruit was considered a low GL food $(\mathrm{GL}=7)$, because the usual portion ingested contains only $11 \mathrm{~g}$ of available carbohydrates (Table 6). In the case of pineapple, the GL proved to be most suitable method to employ when using this kind of food for dietary planning, because it expresses not only the quality, but also quantity of the carbohydrates within a normal portion.

\section{Conclusions}

The edible parts of the pineapple fruit (pulp and core) are rich in soluble carbohydrates and relatively poor in antioxidants and minerals. However, as these fruit tissues are also relatively poor in dietary fiber, the unstirred water layer effect is not expected to occur when pineapple is ingested alone. Therefore, the absorption of minerals and antioxidants would probably be higher due to the lack of interference by the dietary fiber. This fruit in natura is classified as having a low dietary glycemic load $(\mathrm{GL}=7)$, because the usual portion ( $100 \mathrm{~g})$ contains a low concentration of available carbohydrates $(11 \mathrm{~g})$ and a high moisture content ( $90 \%$ approximately). The nutritional composition of the shell and core shows that they cannot be disregarded as a source of a high quality fiber for use in food industry.

\section{Acknowledgements}

The authors wish to acknowledge the XI.18 and 106PI0297 CYTED/CNPq international cooperation projects that facilitated the scientific exchanges between different Ibero-American laboratories.

\section{Reference}

AMERICAN OIL CHEMISTS' SOCIETY - AOCS. Official methods and recommended practices of the AOCS. Champaign, 1989.

AMERICAN OIL CHEMISTS' SOCIETY - AOCS. Official methods and recommended practices of the AOCS. Champaign, 1999.

BATTE, H. D.; MARANGONI, A. G. Fractal growth of milk fat crystals is unaffected by microstructural confinement. Crystal Growth and Design, v. 5, n. 5, p. 1703-1705, 2005.

BERGER, K. G.; JEWELL, G. G.; POLLITT, R. J. M. Oils and fats. In: VAUGHAN, J. G. Food microscopy. London: Academic Press, 1979. p. 445-497.

CAMPOS, R.; NARINE, S. S.; MARANGONI, A. G. Effect of cooling rate on structure and mechanical properties of milk fat and lard. Food Research International, v. 35, n. 10, p. 971-981, 2002.

CISNEROS, A. et al. Polymorphic transformation in mixtures of highand low-melting fractions of milk fat. Journal Agricultural Food Chemistry, v. 54, n. 16, p. 6030-6033, 2006.

D’AGOSTINI, D.; FERRAZ, R. C.; GIOIELLI, L. A. Consistência de misturas binárias e ternárias de gorduras de palma, palmiste e triacilgliceróis de cadeia média. Revista Brasileira de Ciências Farmacêuticas, v. 36, n. 1, p. 147-155, 2000.

DÍAZ GAMBOA, O. W.; GIOIELLI, L. A. Comportamento de cristalização de lipídios estruturados obtidos a partir de gordura de palmiste e óleo de peixe. Química Nova, v. 29, n. 4, p. 646-653, 2006.

DIBILDOX-ALVARADO, E. et al. Effects of crystalline microstructure on oil migration in a semisolid fat matrix. Crystal Growth and Design, v. 4, n. 4, p. 731-736, 2004.

GERMAN, J. B.; SIMONEAU, C. Phase transitions of edible fats and triglycerides: theory and applications. In: RAO, M. A.; HARTEL, R. W. Phase/State transitions in foods. New York: Marcel Dekker, 1998. p. 187-216.

GHOTRA, B. S.; DYAL, S. D.; NARINE, S. S. Lipid shortenings: a review. Food Research International, v. 35, n. 10, p. 1015-1048, 2002.

GIOIELLI, L. A.; SIMÕES, I. S.; RODRIGUES, J. N. Crystal morphology and interactions of binary and ternary mixtures of hydrogenated fats. Journal Food Engineering, v. 57, n. 4, p. 347-355, 2003.

GRALL, D. S.; HARTEL, R. W. Kinetics of butterfat crystallization. Journal American Oil Chemists' Society, v. 69, n. 8, p. 741-747, 1992.

HAIGHTON, A. J. The measurement of the hardness of margarine and fats with cone penetrometers. Journal American Oil Chemists' Society, v. 36, n. 8, p. 345-348, 1959.

HERRERA, M. L. et al. Isothermal crystallzation of hydrogenated sunflower oil: 1. Nucleation. Journal American Oil Chemists' Society, v. 75, n. 10, p. 1273-1280, 1998.

HERRERA, M. L.; GATTI, M. L.; HARTEL, R. W. A kinetic analysis of crystallization of a milkfat model system. Food Research International, v. 32, n. 4, p. 289-298, 1999b.

HIMAWAN, C.; STAROV, V. M.; STAPLEY, A. G. F. Thermodynamic and kinetic aspects of fat crystallization. Advances Colloid Interface Science, v. 122, n. 1-3, p. 3-33, 2006.

HUI, Y. H. Bailey's industrial oil and fat products. 5 ed. New York: Wiley-Interscience, 1996. (v. 2 e v. 3)

KRISHNA, B. et al. Plastic fats and margarines through fractionation, blending and interesterification of milk fat. European Journal Lipid Science Technology, v. 109, n. 1, p. 32-37, 2007. 
LIANG, B. et al. Approches to quantification of microstructure for model lipid systems. Journal American Oil Chemists' Society, v. 83, n. 5, p. 389-399, 2006.

LITWINENKO, J. W.; SINGH, A. P.; MARANGONI, A. G. Effects of glycerol and Tween 60 on the crystallization behavior, mechanical properties, and microstructure of a plastic fat. Crystal Growth and Design v. 4, n. 1, p. 161-168, 2004.

LOPEZ, C. et al. Thermal and structural behavior of anhydrous milk fat. 3. Influence of cooling rate. Journal Dairy Science, v. 88, n. 2, p. 511-526, 2005.

MARANGONI, A. G. Fat crystal networks. New York: Marcel Dekker, 2005. 854 p. MARANGONI, A. G.; ROUSSEAU, D. Chemical and enzymatic modification of butterfat and butterfat-canola oil blends. Food Research International, v. 31, n. 8, p. 595-599, 1998a.

MAZZANTI, G. et al. Effect of minor components and temperature profiles on polymorphism in milk fat. Crystal Growth and Design, v. 4, n. 6, p. 1303-1309, 2004.

METIN, S.; HARTEL, R. W. Thermal analysis of isothermal crystallization kinetics in blends of cocoa butter with milk fat or milk fat fractions. Journal American Oil Chemists' Society, v. 75, n. 11, p. 1617-1624, 1998.

NARINE, S. S.; MARANGONI, A. G. Microscopic and rheological studies of fat crystal networks. Journal Crystal Growth, v. 198-199, n. 2, p. 1315-1319, 1999c.

NARINE, S. S.; MARANGONI, A. G. Relating structure of fat crystal networks to mechanical properties: a review. Food Research International, v. 32, n. 4, p. 227-248, 1999d.

NARINE, S. S.; MARANGONI, A. G. Factors affecting the texture of plastic fats. INFORM, v. 10, n. 6, p. 565-570, 1999a.

PISKA, I. et al. Properties and crystallization of fat blends. Journal Food Engineering, v. 77, n. 3, p. 433-438, 2006.

RODRIGUES, J. N. Reestruturação da gordura do leite por mistura e interesterificação com óleo de milho. 2002. 119 p. Dissertação (Mestrado) - Universidade de São Paulo, São Paulo.

RODRIGUES, J. N.; ANTON, C.; GIOIELLI, L. A. Cristalização de lipídios estruturados obtidos a partir de gordura do leite e óleo de milho. Revista Brasileira Ciências Farmacêuticas, v. 39, n. 1, p. 93-103, 2003a.

RODRIGUES, J. N.; GIOIELLI, L. A. Chemical interesterification of milkfat and milkfat-corn oil blends. Food Research International, v. 36, n. 2, p. 149-159, 2003.

RODRIGUES, J. N.; GIOIELLI, L. A.; ANTON, C. Propriedades físicas de lipídios estruturados obtidos de misturas de gordura do leite e óleo de milho. Ciência Tecnologia Alimentos, v. 23, n. 2, p. 226-233, 2003b.

RODRIGUES, J. N. et al. Caracterização físico-química de creme vegetal enriquecido com ésteres de fitosteróis. Revista Brasileira Ciências Farmacêuticas, v. 40, n. 4, p. 505-520, 2004.
ROUSSEAU, D. et al. Restructuring butterfat through blending and chemical interesterification: 1. Melting behavior and triacylglycerol modifications. Journal American Oil Chemists' Society, v. 73, n. 8, p. 963-972, 1996a.

ROUSSEAU, D.; HILL, A. R.; MARANGONI, A. G. Restructuring butterfat through blending and chemical interesterification: 2. Microstructure and polymorphism. Journal American Oil Chemists' Society, v. 73, n. 8, p. 973-981, 1996b.

ROUSSEAU, D.; HILL, A. R.; MARANGONI, A. G. Restructuring butterfat through blending and chemical interesterification: 3 . Rheology. Journal American Oil Chemists' Society, v. 73, n. 8, p. 983-989, 1996c.

ROUSSEAU, D.; MARANGONI, A. G. The effects of interesterification on physical and sensory attributes of butterfat and butterfat-canola oil spreads. Food Research International, v. 31, n. 5, p. 381-388, 1999.

ROUSSEAU, D.; MARANGONI, A. G.; JEFFREY, K. R. The influence of chemical interesterification on physicochemical properties of complex fat systems: 2. Morphology and polymorphism. Journal American Oil Chemists' Society, v. 75, n. 12, p.1833-1839, 1998.

SATO, K. Crystallization behaviour of fats and lipids - a review. Chemical Engineering Science, v. 56, n. 7, p. 2255-2265, 2001.

SILVA, R. C.; ESCOBEDO, J. P.; GIOIELLI, L. A. Comportamento de cristalização de lipídios estruturados por interesterificação química de banha e óleo de soja. Química Nova, v. 31, n. 2, p. 330-335, 2008.

SIMÕES, I. S.; GIOIELLI, L. A. Microscopia da cristalização parcial de misturas de gorduras hidrogenadas e óleo de soja. Revista Brasileira Ciências Farmacêuticas, v. 35, n. 2, p. 259-266, 1999.

SIMÕES, I. S.; GIOIELLI, L. A. Crystal morphology of binary and ternary mixtures of hydrogenated fats and soybean oil. Brazilian Archives Biology Technology, v. 43, n. 2, p. 241-248, 2000.

SOTERO-SOLIS, V. E.; GIOIELLI, L. A. Estrutura cristalina de las grasas hidrogenadas del aceite de castaña de Brasil (Bertholletia excelsa). Alimentaria, v. 38, n. 322, p. 131-137, 2001.

TANG, D.; MARANGONI, A. G. Quantitative study on the microstructure of colloidal fat crystal networks and fractal dimensions. Advances Colloid Interface Science, v. 128-130, n. 1, p. 257-265, 2006.

TIMMS, R. E. Crystallization of fats. In: HAMILTON, R. J. Developments in oils and fats. London: Chapman \& Hall, 1995. p. 204-223.

TORO-VAZQUEZ, J. F. et al. Crystallization kinetics of palm stearin in blends with sesame seed oil. Journal American Oil Chemists' Society, v. 77, n. 3, p. 297-310, 2000.

WRIGHT, A. J. et al. The effect of minor components on milk fat crystallization. Journal American Oil Chemists' Society, v. 77, n. 5, p. 463-475, 2000.

WRIGHT, A. J. et al. Rheological properties of milkfat and butter. Journal Food Science, v. 66, n. 8, p. 1056-1071, 2001. 